\title{
Mangroves as fish habitat: 50 years of field studies
}

\author{
Craig H. Faunce ${ }^{1,3, *}$, Joseph E. Serafy ${ }^{1,2}$ \\ ${ }^{1}$ Division of Marine Biology and Fisheries, Rosenstiel School of Marine and Atmospheric Science, University of Miami, \\ 4600 Rickenbacker Causeway, Miami, Florida 33149, USA \\ ${ }^{2}$ Southeast Fisheries Science Center, National Marine Fisheries Service, 75 Virginia Beach Drive, Miami, Florida 33149, USA \\ ${ }^{3}$ Present address: Florida Fish and Wildlife Conservation Commission, Fish and Wildlife Research Institute, \\ Tequesta Field Laboratory, 19100 SE Federal Highway, Tequesta, Florida 33469, USA
}

ABSTRACT: Mangroves dominate undisturbed natural shorelines of many sub-tropical and tropical regions, yet their utilization by fishes is poorly understood. To provide the first comprehensive list of empirical field studies for comparative and reference purposes, we assembled and quantified aspects of 111 mangrove-fish surveys published between 1955 and 2005. Differences in the location, purpose, methodology, data gathered, and analyses performed among studies have resulted in a fragmented literature making cross-study comparisons difficult, at best. Although the number of published studies has increased over time, a geographical bias in the literature has persisted towards studies performed in the USA and Australia, and against studies performed in Southeast Asia and West Africa. The typical survey design has examined $<10$ fixed locations on a monthly or bimonthly basis for a period of less than 2 yr. Water temperature and salinity measurements have been the most reported habitat variables; others, such as structural and landscape measures, continue to be rare. Moreover, the focus to date has been on identifying assemblage-level patterns of fish use, with very few studies providing species-specific estimates of abundance, growth, mortality, and secondary production. Unless future studies strive towards obtaining such estimates, gauging the importance of mangroves as fish habitat and their broader contribution to ecosystem diversity and production will remain elusive.

KEY WORDS: Fishes - Essential fish habitat - Mangroves · Nursery $\cdot$ Review

Resale or republication not permitted without written consent of the publisher

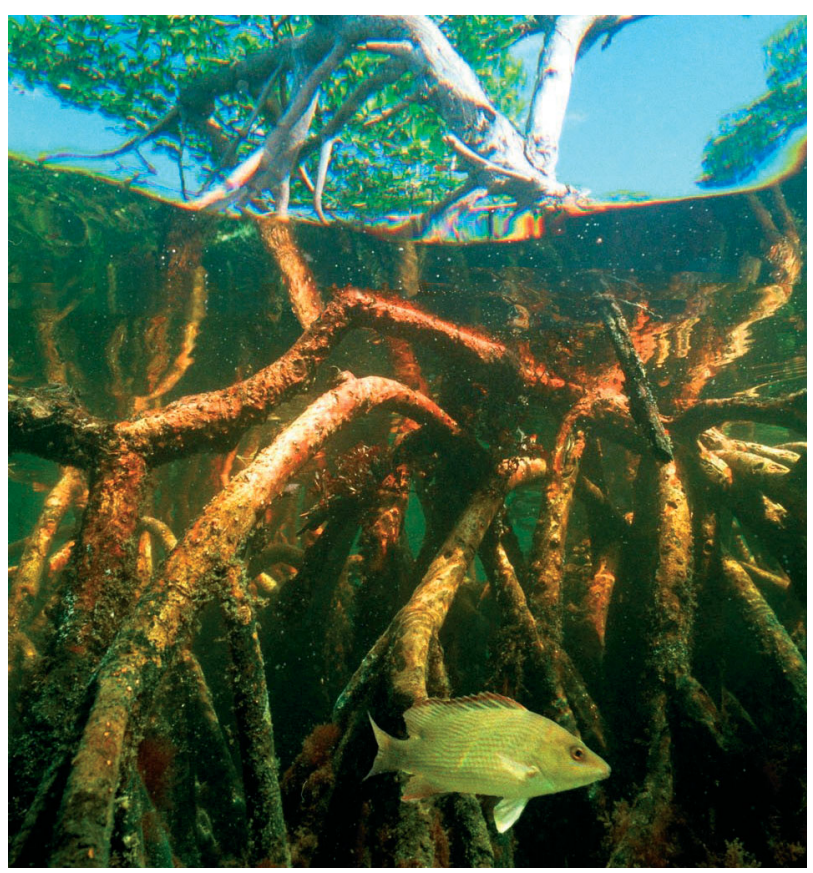

Faunce \& Serafy review mangrove fish studies, focusing on sampling methodology, and on the types of fish and habitat data reported. While most studies have addressed spatiotemporal patterns in fish assemblage structure, speciesspecific estimates of fish mortality, growth and secondary production are still required for appraisal of the importance of mangroves as fish habitat.

Photo: Jiangang Luo

\section{INTRODUCTION}

Mangrove wetlands are a dominant feature of undisturbed tropical and subtropical shorelines around the globe. Throughout their range, however, these habi- 
tats are in a state of decline. Approximately one-third of the world's mangrove forests has been lost to coastal development over the past 50 yr (Alongi 2002). While there is general agreement that mangroves provide a buffer against storm surges, reduce shoreline erosion and turbidity, absorb and transform nutrients, and are inhabited by a variety of organisms, opinions vary as to the importance of mangrove habitats to fishes and, by extension, to offshore fisheries (Thollot \& Kulbicki 1988, Blaber et al. 1989, Thollot 1992, Nagelkerken et al. 2001). For example, the sub-tidal prop-root habitats of mangroves are often cited as nurseries for fishes of economic importance. Today, the protection of mangroves worldwide is based almost entirely on their purported importance to fisheries and/or a number of rare and endangered species (Snedaker 1989, Baran \& Hambrey 1998). However, because the same mangrove species can often occur under marine, estuarine, and freshwater conditions, a wide variety of fish assemblages can be found among their inundated prop-roots (hereafter termed 'mangrove habitats'). As such, mangrove habitats likely play a variety of roles in the lives of associated fishes; feeding areas for some species or life stages, daytime refugia for others, nursery and/or nesting areas for yet more. This situation suggests that questions regarding the contribution of a given mangrove habitat to the diversity, productivity and stability of broader fish communities (and their exploited components) must be carefully qualified, or, in some cases, may be premature.

The purpose of this paper is to address some of the most basic questions regarding the body of literature on mangrove fishes that has been published over the past 5 decades. These questions include: How many field studies have been conducted, why and where were they performed, and what techniques were used? What types of measurements have been made of the fish assemblages, their component species and their habitats? Is there sufficient basis for comparing assemblages of mangrove fishes with those associated with other, structurally-complex habitats, such as seagrass beds and coral reefs? The answers to these questions are pertinent to researchers about to embark on new studies, as well as to those making efforts to balance natural resource protection with pressing socio-economic considerations.

\section{METHODS}

Publications for this review were selected from 3 databases. First, a search of the Aquatic Sciences and Fisheries Abstracts (ASFA) electronic database was conducted (Cambridge Scientific Abstracts; www. csa.com) using keyword and title searches for the words 'mangrove(s)' and/or 'fish(es)'. Records were selected from the earliest available time period (1971) to January, 2005. The resulting list of over 500 publications was reduced to relevant works according to 2 main criteria: (1) the study must have been published in readily available outlet (i.e. in the 'primary literature'); and (2) each publication must have contained a field-based survey of the ichthyofauna that was conducted within a natural mangrove system. Second, the Science Citation Index (Web of Science; http://isi5. newisiknowledge.com) was used to identify articles that cited works from our reduced ASFA list. Again, any additional publications were vetted according to the selection criteria above. Third, articles from the authors' personal libraries and those introduced through peer review (of this paper) were added. The references cited in each relevant article were examined for new items and this process was continued until no additional publications emerged.

Study locations were grouped into 5 geographic regions following the World Mangrove Atlas (Spalding et al. 1997): (1) South and Southeast Asia (Pakistan to the west, China and Japan to the northeast, including Indonesia), (2) Australasia (Australia, Papua New Guinea, New Zealand, and the South Pacific islands), (3) the Americas (north, central, and south), (4) West Africa, and (5) East Africa and the Middle East (Iran to South Africa eastwards, including the islands in the Indian Ocean). Using the selection (foraging) ratio of Savage (1931), geographical bias in the literature was expressed as the proportion of total studies realized per region relative to the area of mangrove coverage within each region (Manly et al. 1993).

The study purpose, methodology, data gathered, and analyses performed were extracted and tabulated using vote-counting procedures, where 'present' was given a value of 1 and 'absent' was given a value of 0 . Data were expressed as proportions of the total number of votes per attribute. Study purposes included identifying spatial or temporal patterns, generating species lists, identifying explanatory variables, biogeographic comparisons, restoration, water management, and gear evaluations. Methodologies included the sampling design (fixed, random, haphazard, or various), sampling frequency (daily, weekly, fortnightly, monthly, bimonthly, quarterly, seasonally, semi-annually) sampling duration, and gear type. Gear types were classified according to Rozas \& Minello (1997) and included entanglement gear (gill or trammel nets), towed nets (trawls, seines), passive samplers (fyke nets, flume nets, rotenone-used with or without nets, fish traps, e.g. breder, plankton), and 'enclosure samplers' (block or drop nets, drop traps, and cast nets). Visual surveys and angling were added as additional gears. The type of mangrove forest sampled was noted 
using the classification scheme of Lugo \& Snedaker (1974), which included fringing, riverine and/or basin forest. The data gathered in each study included biotic and abiotic habitat metrics. Fish metrics included groupings by family, maturation stage, residency status, trophic level, or diel habits as well as the type of fish data gathered and analyzed. We classified the types of fish metric data reported in each study according to the criteria recommended for determining 'essential fish habitat' (EFH) (USDOC 1996) which included: presence/absence, frequency of occurrence, percent composition, size, biomass (g), density (number/area), standing crop (g/area), growth and mortality rates, and rates of secondary production. Finally, the focus of analyses (e.g. defining spatial and/or temporal patterns, examining fish-habitat correlations) was tabulated and the type of statistical test(s) or data treatment(s) performed (similarity measures, analysis of variance, ordination, or regression) were recorded.

\section{RESULTS AND DISCUSSION}

\section{Chronology and geography}

A total of 111 publications were examined from 104 independent field surveys of mangrove fishes published between 1955 and 2005 (Table 1). The earliest records of mangrove-associated fishes were species lists compiled by Inger (1955) and Boeseman (1963) as part of broad ecological inventories of forests in Borneo (South and Southeast Asia region) and the Niger Delta (West Africa region), respectively. Austin (1971) provided the first inventory of mangrove fishes from Puerto Rico (American region), and Day (1974) from Mozambique (i.e. the East Africa and Middle East region). Blaber (1980), and Blaber \& Blaber (1980) published the first of many works on assemblages of mangrove fishes from Australia (Australasian region).

While the cumulative number of publications has grown steadily since the mid 1980s, the sharpest increases occurred for the regions of South and Southeast Asia and the Americas (Fig. 1). Selection indices indicate that the geographic distribution of studies among regions has not been commensurate with the proportion of the world's mangrove acreage that they contain (Table 2). Nearly $70 \%$ of studies have been conducted in either the Americas or Australasia, and the South and Southeast Asia and West Africa regions are clearly under-represented in the literature. Because South and Southeast Asia contains the largest proportion of the world's mangrove coverage, it is encouraging that more literature is emerging from this region where coastal fish assemblages are also relatively diverse (Blaber 2002). However, a literature void remains for the West Africa region-an area that is likely to continue to be underrepresented unless specifically targeted for study. Interestingly, the first 2 studies of mangrove fishes were conducted in the 2 regions that are least represented today.

Although disproportionate, the spatial distribution of studies we examined covers much of the known global distribution of mangroves (Fig. 2). Specific areas that have received the most thorough study include Florida (USA) and Moreton Bay (Australia). Similar dominance of studies from the USA and Australia in the literature has beset previous reviews of fishes occupying seagrass beds (Heck et al. 2003), mangroves (Sheridan \& Hays 2003), and studies of ontogenetic fish movements (Gillanders et al. 2003). Regions outside US and Australian waters where data are particularly lacking include: (1) Pacific Panama; (2) Colombia; (3) Central Brazil; (4) the Red Sea; (5) Mozambique; (6) the Bay of Bengal and the Andaman Sea; and (7) Borneo (Fig. 2). However, there are several important cases where fishes inhabiting tropical estuaries from these areas have been reported. In such cases, data summaries were made from multiple surveys of fishes that rarely mentioned study objectives, methods, gear, or habitat(s) sampled, making their inclusion here difficult, at best. In Florida (USA), species lists of mangrove fishes were compiled from numerous studies by Odum et al. (1982) and presented for tidal streams, estuarine bays, and oceanic bays. Off Columbia, Alvarez León \& Blanco Racedo (1985) reviewed aspects of 31 studies conducted in the Cartagena Bay system. They provided an overall species list for the system, and sum-

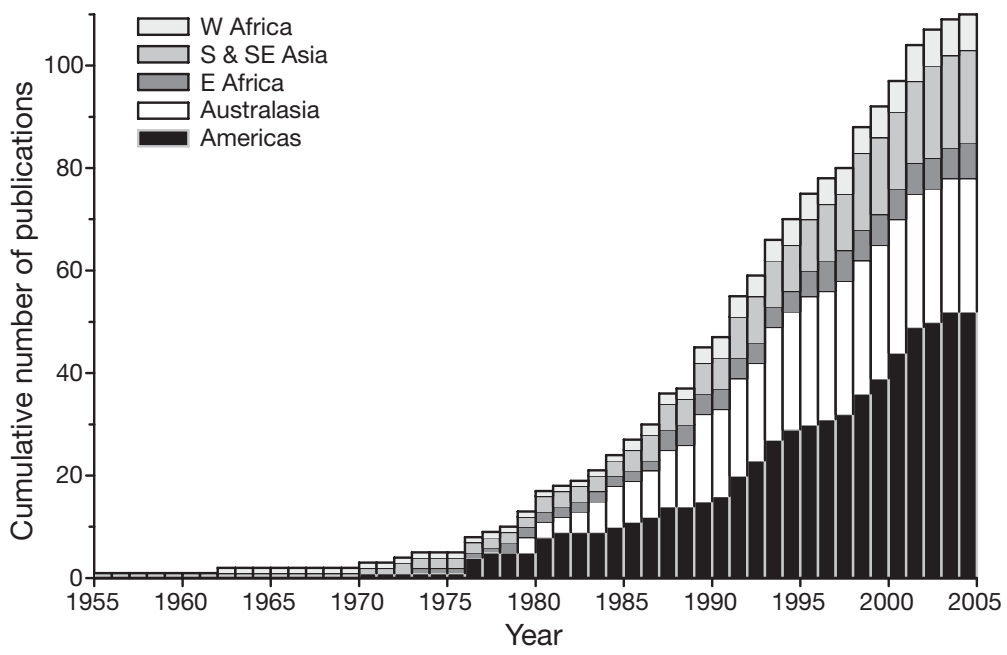

Fig. 1. Cumulative number of publications on mangrove fishes by each geographic region from 1955 to 2005 ( $\mathrm{n}=111)$ 


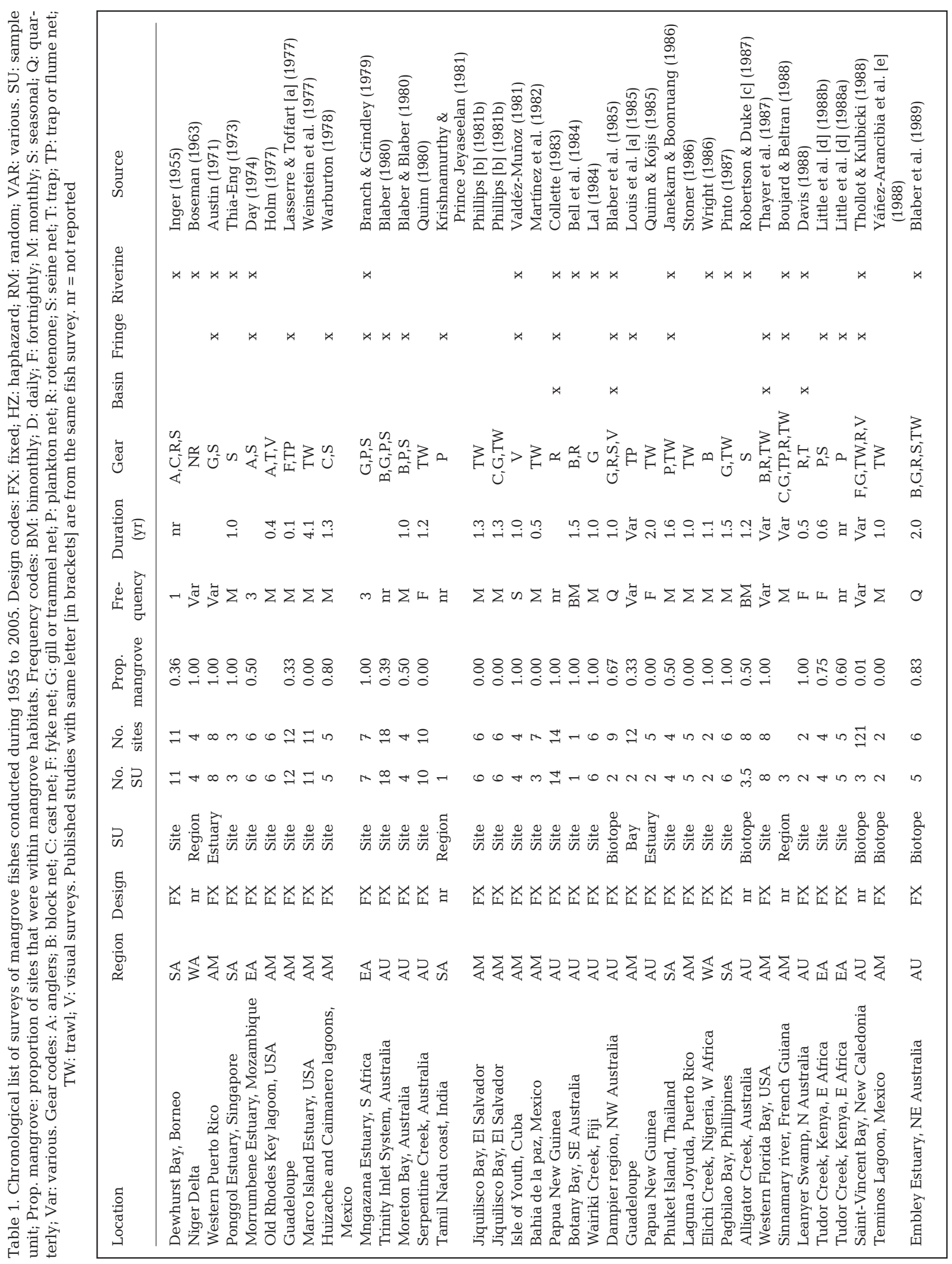




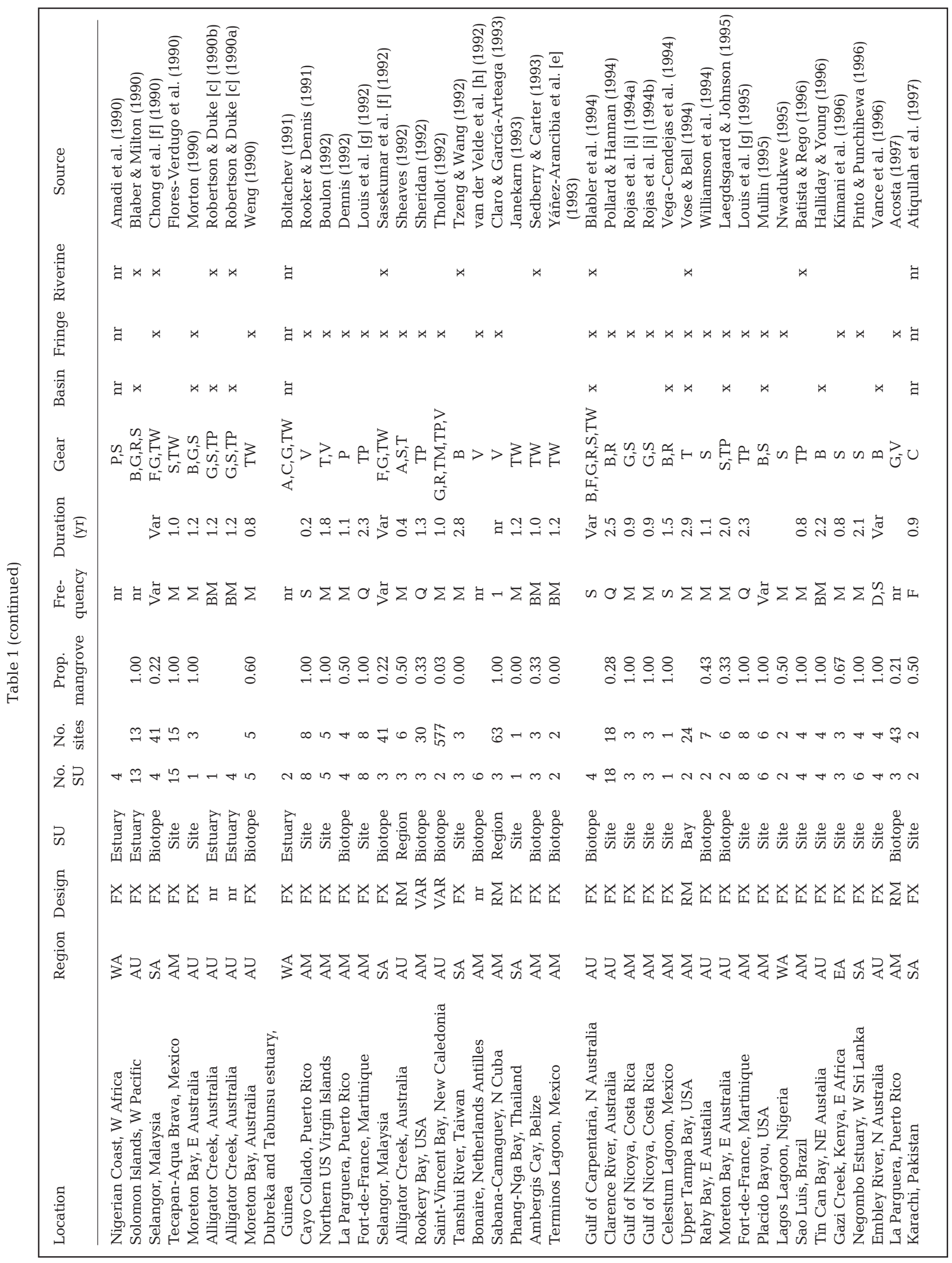




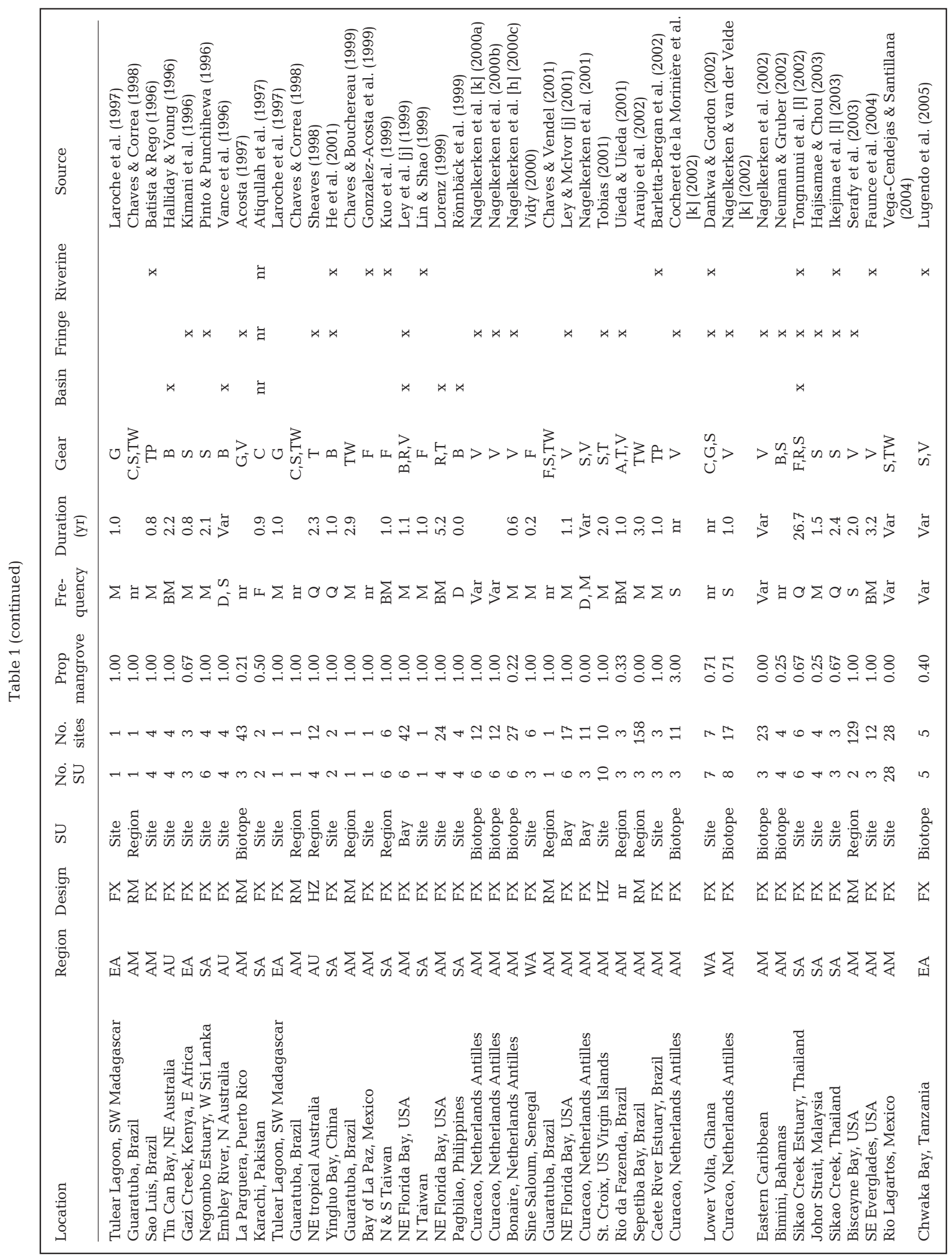




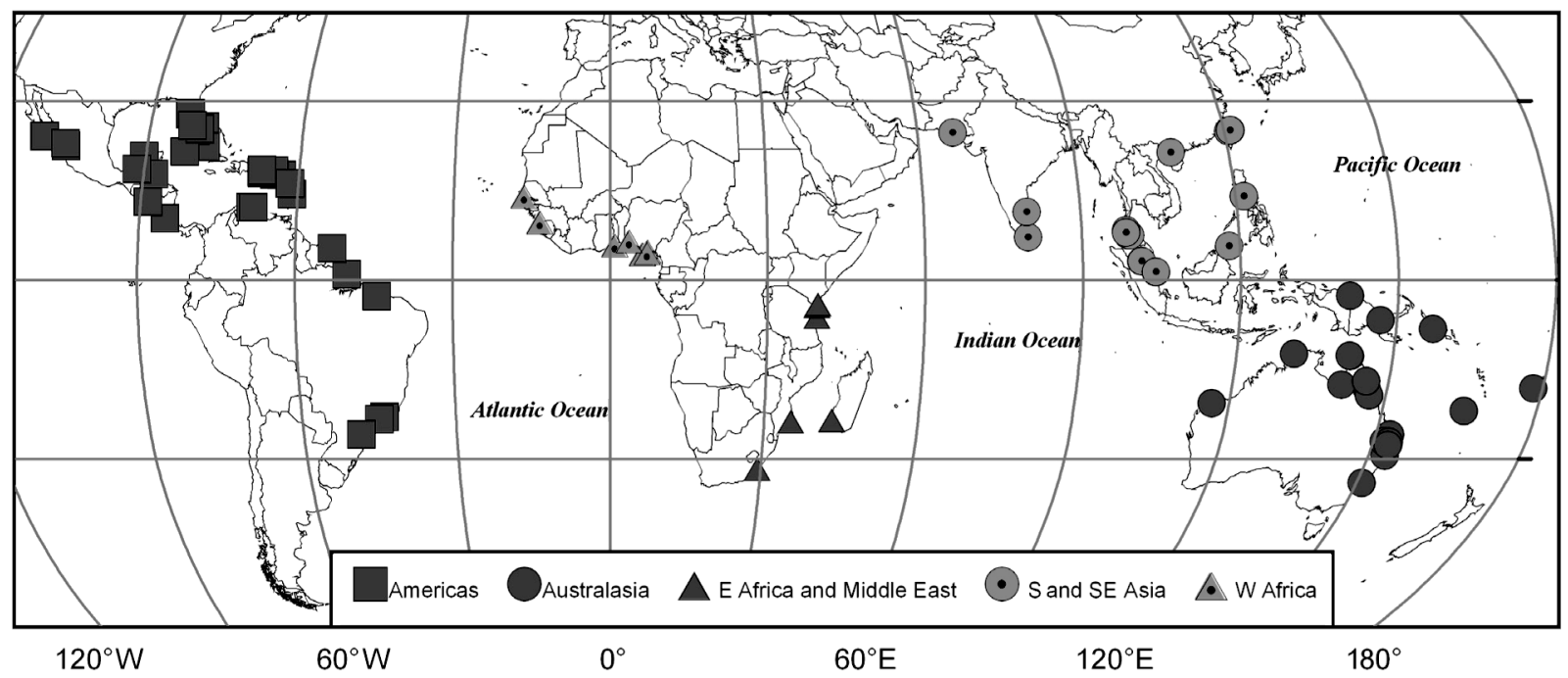

Fig. 2. Location of studies of mangrove fishes used in the present review (coded by geographic region)

marized their data based on the number of species belonging to various salinity regimes and trophic levels for Bahía de Cartagena, Ciénaga de Tesca, and Ciénaga Grande de Santa Marta. Similarly, Cervigón (1985) used data from an earlier study and historical records to generate a list of fish species for the Orinoco estuary (Venezuela) according to salinity regime. Finally, the ecology of the Itamaracá ecosystem (Brazil) was summarized by Paranagua \& Eskinazi-Leça (1985), who provided a family and species list of fishes. For more complete summaries of fish studies conducted from large tropical estuarine systems, the reader should consult the comprehensive works of Blaber (2000) and Yáñez-Arancibia (1985).

\section{Study design}

Study design incorporates a study's purpose with its methodology. Over half of the examined surveys of mangrove fishes aimed to identify spatial and/or temporal patterns of mangrove utilization, while a lesser proportion were conducted to provide an inventory of fishes $(21.7 \%)$ or identify explanatory variables for observed utilization patterns $(15.6 \%)$. Less than $10 \%$ of studies were concerned with the remaining topics (Fig. 3a). Most studies aimed to identify temporal patterns, and typically achieved this goal through monthly sampling for a period of 0.5 to $1.5 \mathrm{yr}$ (Fig. 3b,c). Sampling durations of more than 2 yr were uncommon $(<5 \%)$ with the longest published survey spanning $5 \mathrm{yr}$ (Lorenz 1999). In addition, most studies sampled, or otherwise quantified, fishes at a small number of locations. Only 4 studies sampled mangroves at more than 20 locations: Serafy et al. (2003) sampled 129 locations, Claro \& García-Arteaga (1993) sampled 63 locations, Ley et al. (1999) sampled 42 locations, and Lorenz (1999) sampled 24 locations (Table 1). Fixed sampling designs were employed much more often (81\%) than random-stratified $(8.5 \%)$ or haphazard designs $(1.8 \%)$ or various other sampling designs $(1.8 \%)$. In fixed- and mixed-design surveys, the rationale for selecting site locations was rarely provided.

These results highlight some limitations with our knowledge of mangrove habitat utilization by fishes. For example, if not selected remotely, or a priori, the

Table 2. Comparison of mangrove area and the number of published studies from within each geographic region. The selection ratio $\left(\mathrm{w}_{\mathrm{i}}\right)$ of Savage (1931) was used to compare the proportion of studies to the proportion of mangrove area within each region

\begin{tabular}{|lcccr|}
\hline Region & $\begin{array}{c}\text { Mangrove } \\
\text { area }\left(\mathrm{km}^{2}\right)\end{array}$ & $\begin{array}{c}\text { Proportion of } \\
\text { total area }\end{array}$ & $\begin{array}{c}\text { Number of } \\
\text { total studies }\end{array}$ & $\begin{array}{c}\text { Proportion of } \\
\text { total studies }\end{array}$ \\
\hline Americas & 49096 & 0.271 & 53 & 0.477 \\
Australasia & 18789 & 0.104 & 26 & 0.234 \\
East Africa and Middle East & 10024 & 0.055 & 7 & 0.063 \\
South and Southeast Asia & 75173 & 0.415 & 18 & 0.162 \\
West Africa & 27995 & 0.155 & 7 & 0.063 \\
Total & 181077 & & 111 & 0.147 \\
\end{tabular}



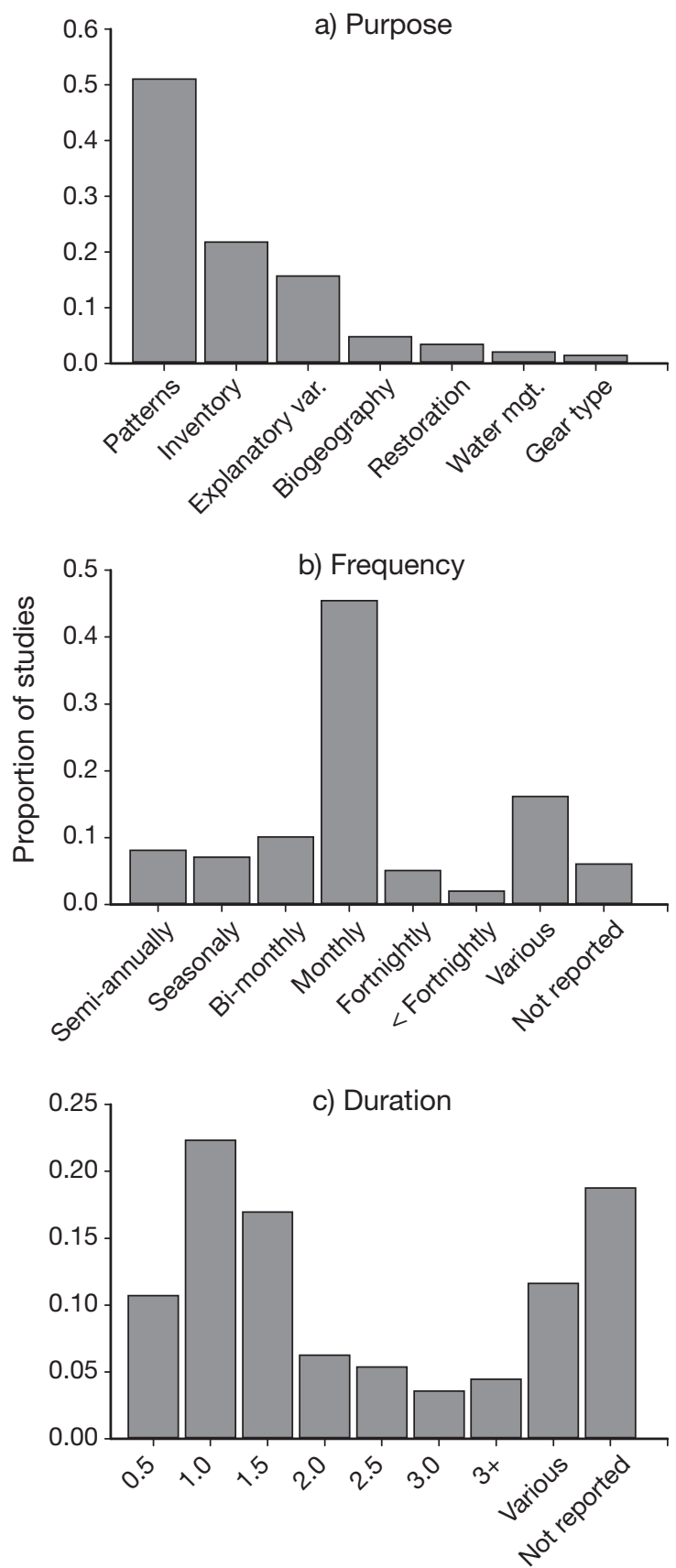

Fig. 3. (a) Purpose, (b) sampling frequency, and (c) sampling duration (in yr) of studies of mangrove fishes. Var: variable; mgt: management. Note difference in $y$-axis scales

choice of sampling locations may be biased, which in turn can be reflected in the data gathered (Rozas \& Minello 1997). In addition, the limited spatial extent and/or small number of sites sampled in most studies may not be representative of a given area or region, and thus may be of limited use to coastal resource managers if they must determine the costs and benefits of developing one mangrove area over another. Similarly, the lack of multi-year studies precludes assess- ment of what constitutes a 'typical' year, or of the extent of inter-annual variability in both the fish assemblages and their environment. While the seasonal dynamics of mangrove use by fishes has received attention, only a few studies have focused on shorter temporal scales. In the future, researchers should better describe how and why sampling locations were selected, and when possible include the rationale behind their sampling intensity/allocation decisions.

How fish samples have been acquired from mangroves is of particular importance due, in part, to issues of species- and size-selectivity. Indeed, one of the major reasons mangroves have received relatively little attention as fish habitats is that it is inherently difficult to quantitatively sample fishes within them. Consequently, our understanding of the role(s) that these habitats play in the lives of fishes has been hindered by the fact that the same sampling methods have rarely been used from one study to the next. Over one-third of all studies we reviewed used towed gears, which is a consistent finding among geographic regions (Fig. 4a,b). While towed nets can be effective in seagrass beds, they are of little or no use within the dense, rigid, entangled roots of mangrove trees. Use of pas-

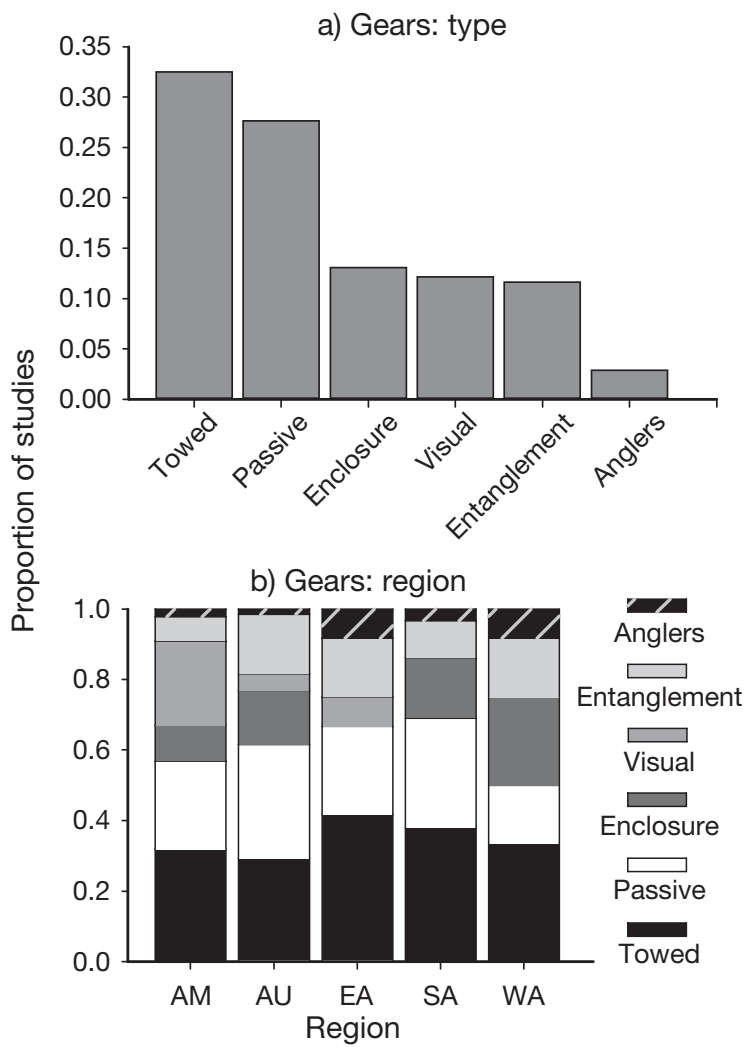

Fig. 4. The gear type used to collect fishes from mangrove habitats (a) among studies, and (b) by geographic region. AM: Americas; AU: Australasia; EA: East Africa and the Middle East; SA: South and Southeast Asia; WA: West Africa. Note difference in $y$-axis scales 
sive gears has also been common (27\% of studies). Most passive gears are difficult to place in dense mangrove prop-roots without constituting additional structure, and like towed gears are often actually employed at the periphery of the mangrove shoreline. This considered, one out of 5 purported studies of mangrove fishes that we reviewed failed to sample within mangrove habitat. This has undoubtedly produced unrepresentative data in specific cases, and has probably led to unfounded conclusions about the nature and extent of fish utilization of mangroves in general.

There are notable exceptions, however, where more appropriate sampling techniques have been applied to quantitatively sample fish within the mangroves proper. These include enclosure, entanglement, and visual techniques, which have each been employed with similar frequency (i.e. 11 to $13 \%$ of studies). A common type of enclosure gear uses a fine mesh net to encompass a mangrove area and fishes are subsequently removed with poison and/or a smaller net (e.g. Bell et al. 1984, Thayer et al. 1987, Blaber \& Milton 1990). Such block netting can result in estimates of both abundance and biomass per unit area (standing crop), and is an especially effective method for collecting small, cryptic fishes. However, sampling efficiency is dependent on the clearing method used. Two drawbacks of enclosure samplers are that they often involve both short- and long-term disturbance of the habitat under study (e.g. prop-root and canopy removal), and are relatively labor intensive. In contrast, passive samplers such as fyke, flume, or channel nets do not greatly modify the mangrove habitat, but are limited to situations where tides are sufficient to drain the habitat and effectively force fishes into these capture devices (McIvor \& Odum 1986). Most traps, like entanglement gears, can be rapidly deployed and cause minimal habitat disturbance. These gears can also be effective for catching relatively large (ca. $10 \mathrm{~cm}$ total length) mobile fishes often missed by other gears; however, there are size- and species-selectivity constraints. Size selectivity problems can be reduced by sampling with traps of different mesh sizes and openings, or by sampling with nets with multiple panels composed of different meshes (Sogard et al. 1989, Sheaves 1995). Unfortunately, like all passive samplers, only relative abundance or biomass, rather than density or biomass per unit area, can be estimated using traps and entanglement nets. Finally, underwater visual fish census can be a rapid and effective technique for gathering data and making quantitative comparisons of fish distribution, abundance, and size-structure within and among habitat types. Visual fish census has been utilized in seagrass beds, mangroves, and hardbottom communities, and has become the most accepted method for estimating fish abundance and diversity in coral reef environments (e.g. Lindeman \& Snyder 1999, Nagelkerken et al. 2000b, Russ et al. 2005). An important distinction between visual surveys and other methods is that the former does not capture fishes, and thus is advantageous for studying threatened or endangered species. Limitations of visual surveys stem from variations in visibility, size- and species-specific responses of fish to those performing the survey, observer experience, recording errors, as well as safety concerns (Cheal \& Thompson 1997, Thompson \& Mapstone 1997, Ley et al. 1999). While precision varies by methodology (e.g. roving, timed, or belt transect, written or audio recording media), accuracy problems can be reduced by performing observer training and using a limited number of personnel (Bell et al. 1985, Greene \& Alevizon 1989, St. John et al. 1990). Visual survey techniques were used far more often in studies conducted in the Americas (Caribbean), than in either Australasia or East Africa, and were absent from South and Southeast Asia and West Africa (Fig. 4b).

Given the above, there is clearly no 'best' method for sampling fishes within mangrove habitats. The optimal method will vary according to study constraints and have bias and precision that should be weighed in accordance with the goals of the project. In studies that focus on analyzing the entire assemblage, the application of multiple gear types has been used with success and is preferred (Blaber et al. 1985). With respect to single gear studies, we agree with Rozas \& Minello (1997) that enclosure samplers are superior for quantifying fishes in structurally-complex habitats, especially in turbid waters, and add that visual surveys are particularly useful in clearer waters.

\section{Habitat metrics}

An historical summary of abiotic and biotic measures collected aids our present ability to assess the value of mangroves as fish habitat. Unlike experimental studies that benefit from being able to isolate and manipulate specific variables for study, in the field it is difficult to choose appropriate abiotic (habitat) factors to measure since they are often autocorrelated with one another. While the appropriate environmental variables measured in a study should differ depending on the goals of the project and on local conditions, over half of the habitat metrics recorded in the literature database consisted of temperature and salinity measurements, and this trend was observed across all geographic regions (Fig. 5a,b). Certainly temperature is linked to broad spatial patterns in the use of mangroves by fishes, as more fish species are noted from tropical estuaries than from sub-tropical estuaries, and a positive correlation between temperature and overall assemblage 

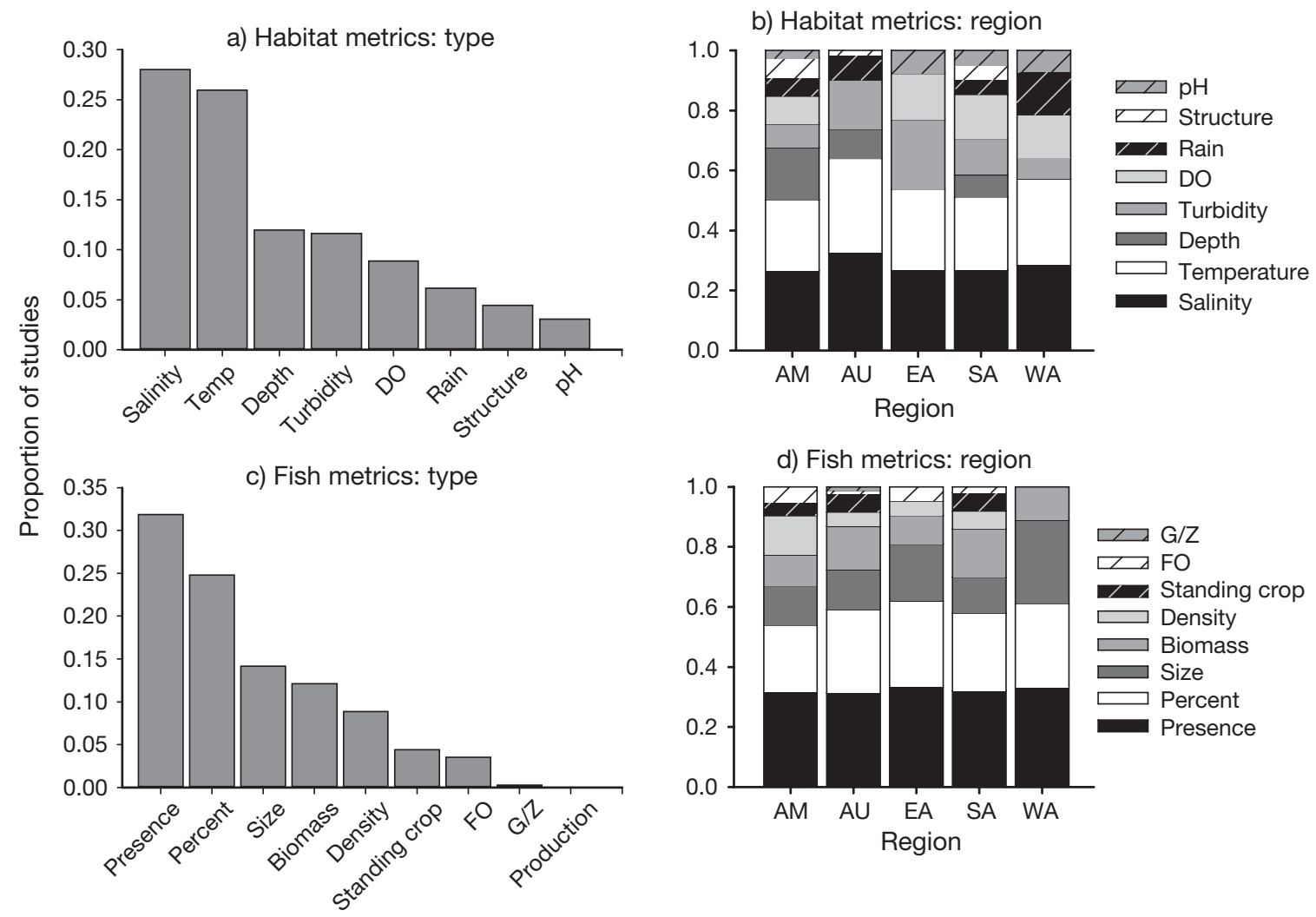

d) Fish metrics: region

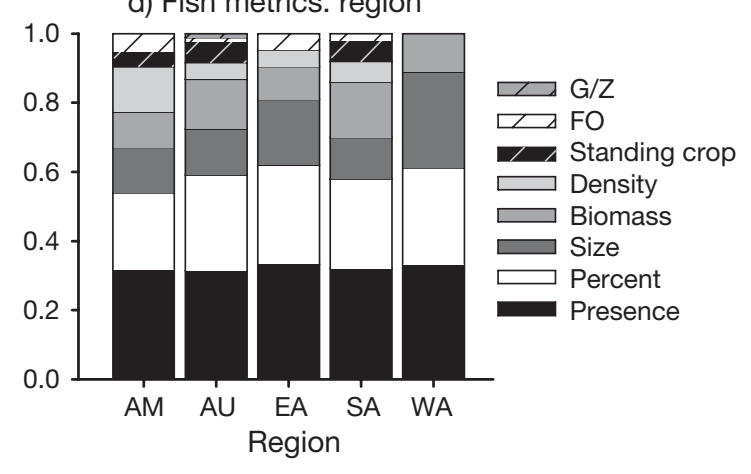

Fig. 5. Summary of $(a, b)$ habitat and $(c, d)$ fish metrics collected from mangroves $(a, c)$ among studies and $(b, d)$ by geographic region. DO: Dissolved oxygen; FO: frequency of occurrence; G/Z: growth and/or mortality estimates; rain: rainfall; temp: temperature. Geographic regions abbreviated as in Fig. 4

richness, diversity, and abundance has been noted by several authors (Robertson \& Duke 1987, Williamson et al. 1994, Lin \& Shao 1999). While seasonal and diel changes in temperature are typically predictable, changes in salinity within a mangrove habitat can be more dynamic. Salinity can either remain relatively stable throughout the year (e.g. along well-connected oceanic islands), exhibit seasonal changes resulting from fluvial runoff, or change dramatically as a result of anthropogenic freshwater releases (Faunce et al. 2004). In addition, observed fish patterns in mangrove habitats may be correlated with: (1) water depth, where the habitat is temporally inundated (e.g. Robertson \& Duke 1990a, Laegdsgaard \& Johnson 1995); (2) turbidity, where sediment transport is (a) high (e.g. Blaber 1980) or (b) in areas without large salinity fluxes; and (3) dissolved oxygen in areas with poor water flow or located downstream of large industrial or agricultural areas (e.g. Claro et al. 2001).

Abiotic regime (i.e. mean, range, and stability) may be of more importance in structuring the assemblage of mangrove fishes than 'snapshot' metrics collected at the time of sampling. For example, a negative relationship between environmental stability and species diversity has been well documented outside the litera- ture on mangrove fishes (Connell 1978, Leigh 1990). However, there is scant evidence suggesting such relationships may also hold for fishes inhabiting mangroves (Serafy et al. 2003). Although regime characterization requires that dynamic abiotic variables are measured over longer periods of time than just on the day of fish sampling, few studies in the literature have examined fish-habitat relationships on multiple time scales (Bell et al. 1984, Lorenz 1999, Faunce et al. 2004).

As in the case for temporal scales, examination of multiple spatial scales may be integral to determining which fishes utilize mangrove habitats and why; yet this has also been largely ignored in the literature on mangrove fishes. At the smallest scales, structural complexity may be important, but this was reported in less than $5 \%$ of studies. It is likely that few field-based studies measured and reported structural measurements because early attempts failed to find meaningful correlations with fish measures (Sheridan 1992, Mullin 1995). Interestingly, experimental studies have demonstrated that the increased structural complexity of mangroves reduces the efficiency of predators (Primavera 1997, Laegdsgaard \& Johnson 2001). At larger scales, many studies have sampled sites located at 
various distances from features upstream (e.g. fresh water) versus downstream (e.g. coral reefs). However, distance values were reported in less than $10 \%$ of studies, and in only 2 instances were they used in analyses with fish metrics (Nagelkerken et al. 2000b, Hajisamae \& Chou 2003). Such analyses can be performed readily given the advances in global positioning satellites and geographic information system technology (e.g. Kendall et al. 2003).

\section{Fish metrics}

Recently, several fish metrics have been reviewed and ranked according to their usefulness for determining the importance of fish habitats, including mangroves. In 1996, the US government mandated that all stock assessments include EFH provisions and consider 4 levels of information (USDOC 1996). On a habitat-specific basis, these include fish presence-absence (Level 1), densities (Level 2), growth, reproduction, and survival rates (Level 3), and secondary production rates (Level 4). A refined definition of 'nursery habitat' emerged with a paper by Beck et al. (2001). They contend that a nursery habitat contains one or more of the following traits compared to other non-nursery habitats: (1) greater densities of young fishes; (2) lower predation rates; (3) higher growth rates; and (4) more successful migration to subsequent habitats (Beck et al. 2001).

In light of these developments, this literature review can be used to answer the question: What information is available to assess the value of mangroves as fish habitat? Presence/absence information was the most widely reported form of fish data, followed closely by percentage composition (Fig. 5c). These 2 metrics accounted for over half the reported entries (31 and $24 \%$, respectively) and were available from almost all surveys of mangrove fishes that we examined. Size information was less prevalent, and was present most often as part of a description of collected fishes. Only 1 publication presented detailed size information for several species over time (Robertson \& Duke 1990b). Biomass information was more prevalent in the literature than either density or standing crop (i.e. numbers and biomass per unit area, respectively), both of which require information about the area sampled (Fig. 5c). Remarkably, frequency of occurrence information (i.e. the proportion of sites or repeated samples that contained at least 1 individual), available from any survey, went unreported in $>90 \%$ of studies. Density, standing crop, and frequency of occurrence data have not been reported from the West African region (Fig. 5d). Perhaps most limiting to mangrove fish habitat assessment is that only 1 estimate of growth (Robertson \&
Duke 1990b), and no estimates of habitat-specific mortality or production have appeared in the literature. Because such studies may have been specifically focused on these biological metrics, it is possible that such studies exist outside the realm of this review. Other biotic factors such as larval supply, predation, competition, and food supply are difficult to consistently and reliably measure, and we were unable to find studies that reported these measures in the literature on mangrove fishes.

\section{Data analyses}

Having summarized where, when, and how fish data have been collected from mangrove habitats, the ensuing discussion is concerned with what has been done with them. Fish abundances were usually analyzed at one of 3 levels: the entire assemblage, 'dominant taxa' (e.g. the 10 most abundant species grouped), or individual species. A measure of the entire assemblage (e.g. total fish density or biomass) was the most commonly used level of analysis (52\%), followed by the analysis of dominant taxa (31.2\%) and then individual species abundances $(16.8 \%)$. As most studies aimed to identify patterns of fish use, analyses were focused on examining temporal and spatial variation (Fig. 6a). Fish-habitat correlations were examined less often, and were completely absent from the West African region. Regardless of the focus, the type of data analysis conducted was typically in the form of simple side-by-side comparisons (Fig. 6b). Similarity indices, ANOVA, and ordination techniques were applied with equal frequency among studies with spatial or temporal emphasis, and less often in studies with a fish-habitat focus; the latter investigation type aloneutilized multiple linear regression techniques.

Simple data comparisons dominated the literature. Comparisons of fish data by family (38.1\%) predominated, probably because this information is presented in species lists (Fig. 7a). Comparing fish groups according to life-history (maturity) stage or as either residents or transients (residency) was also common ( 23.7 and $19.5 \%$, respectively). Comparisons according to trophic groups and diel period were among the least reported in the database. The characterization and comparison of fishes according to their trophic level can be a valuable tool for revealing their role in system energy flow. The concept of using such functional groups as a basis for site and ecosystem comparison and evaluation has recently been reviewed for coral reefs (Bellwood et al. 2004) and holds promise for application to mangrove systems as well. Evidence is mounting that mangroves primarily serve as daytime refugia for a major component of fishes 
a) Analysis focus

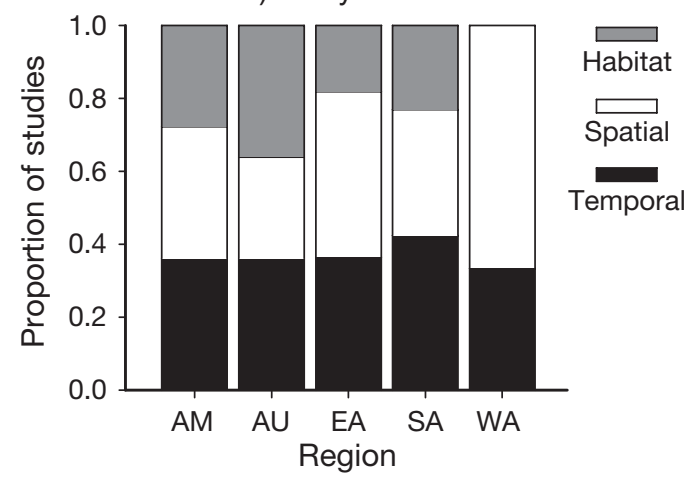

b) Analysis type

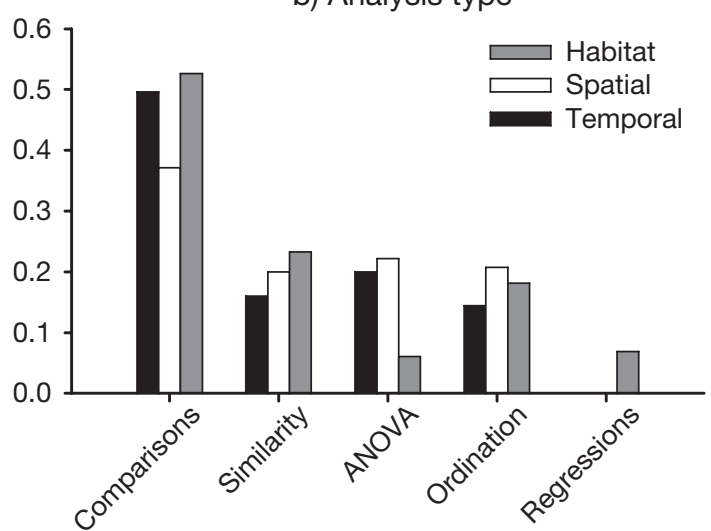

Fig. 6. Data analyses performed within studies of mangrove fishes organized by (a) geographic region and (b) type (i.e. statistical test). Data are organized according to the purpose of analyses: identifying spatial patterns (spatial), identifying temporal patterns (temporal), or exploring fish-habitat interactions (habitat). Non-statistical comparisons of data types (e.g. density) are labeled comparisons. Similarity refers to indices of similarity, diversity, and evenness. Geographic regions abbreviated as in Fig. 4

occupying mangrove shorelines (Rooker \& Dennis 1991, Nagelkerken et al. 2000a, Valdés-Muñoz \& Mochek 2001). This suggests for some species that fish production attributed to mangroves may not necessarily derive from this habitat alone (Adams et al. 2006). Linkages between mangrove shorelines and the proximity, size, and availability of nocturnal foraging areas, such as seagrass beds or mudflats, deserve greater attention.

\section{SYNOPSIS}

This work represents the first attempt to assemble and examine a substantial number of published studies of mangrove fishes. In contrast, previous reviews of the literature on mangrove fishes have been more limited in scope. Thayer \& Sheridan (1999) examined the methods and results of less than 12 studies from Florida (USA), while Sheridan \& Hays (2003) compiled

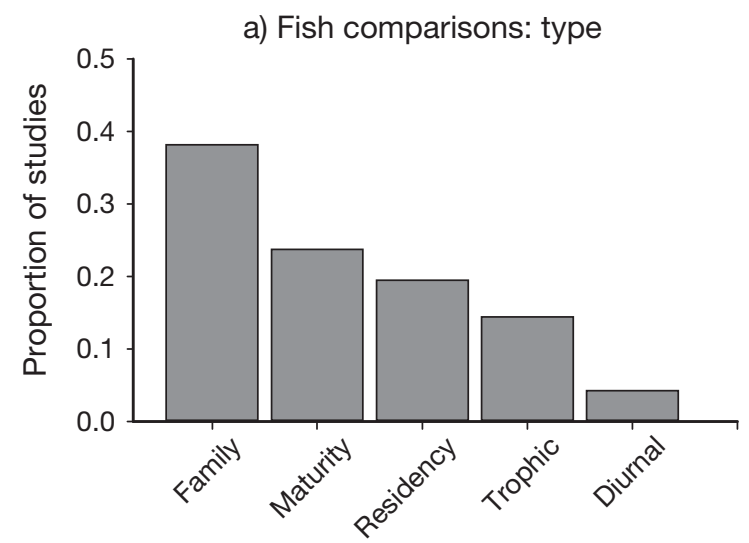

data from 19 studies that quantified fishes within mangroves and at least one other habitat.

\section{Current limitations}

Our review reveals that (1) certain regions, specifically South and Southeast Asia and West Africa, are under-represented in the literature, (2) the majority of surveys were spatially restrictive and/or of short duration, and (3) numerous purported surveys of mangrove fishes failed to sample within mangrove habitats per se. In defense of these studies, most were designed with modest goals in mind: (1) to identify which taxa were present, and (2) to determine their abundances among locations and/or sequential samples. While these studies have been useful in identifying the components and dynamics of various assemblages of mangrove fishes, this type of data provides little information with which to compare and evaluate the

\section{b) Fish comparisons: region}

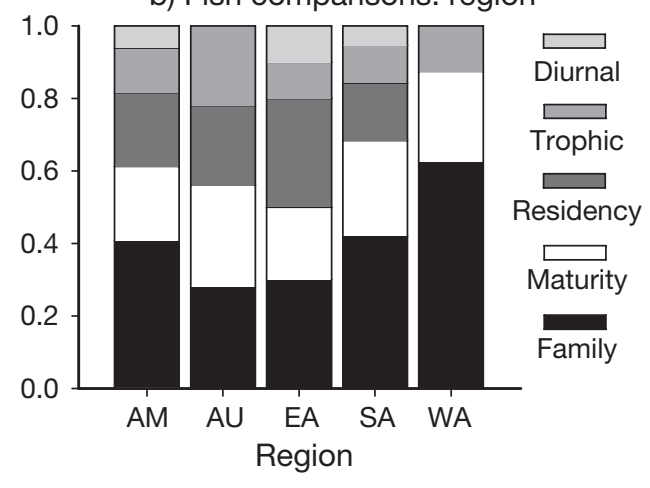

Fig. 7. How fish metrics were grouped for data comparisons (a) among studies, and (b) by geographic region. Geographic regions abbreviated as in Fig. 4 
importance of mangrove habitats for ecosystem diversity and productivity.

Where fish-habitat correlations have been examined, most studies performed analyses at the assemblage level using environmental data obtained at the time of sampling. Consequently, there is meagre information on how individual species respond to environmental variability. This is unfortunate, given that recent works suggest that the nature of the relationship between habitat features and fishes is species- and sizespecific, and that only with this level of understanding can insight into ecological processes be gained (Benedetti-Cecchi 2003, Cocheret de la Morinière et al. 2004). Furthermore, the type of fish metrics reported did not often include those most desired by decision makers. For example, although simple presence/ absence and percentage composition data were commonly reported, size and frequency of occurrence were not, despite the fact that these metrics should be available from any survey that repeatedly samples fishes. The more detailed, difficult-to-collect data needed for mangrove valuation were effectively absent from the database. With possibly 1 exception (i.e. Robertson \& Duke 1990b), no study of mangrove fishes recorded adequate numbers over time, numbers at age, size-frequencies, or tag-recapture data needed for the traditional assessment of growth, mortality, or secondary production. As a result, comparisons of EFH or nursery data from studies of mangrove fishes will likely be limited to density or biomass values only. If the USDOC (1996) or Beck et al. (2001) definitions of these terms are to be used to assess the habitat value of mangroves, future efforts must strive to track cohorts of fish over space and time.

Among the most significant conclusions to draw from this review is that surveys of mangrove fishes are not readily comparable. Hence, the findings of any new study may be either bolstered or refuted using selected references from the relevant literature. For example, findings are mixed in studies relating habitat features to assemblages of mangrove fishes with respect to water temperature (Wright 1986, Lin \& Shao 1999), salinity (Quinn 1980, Ikejima et al. 2003), and turbidity (Little et al. 1988b, Kimani et al. 1996). Different conclusions regarding the fish assemblage may be reached even when 2 studies have been conducted within the same body of water. For example, Williamson et al. (1994), who sampled with $8 \mathrm{~mm}$ mesh beach seine in Raby Bay, Australia, reported, 'the majority of fish captures were either small species or juveniles', while Moreton (1990) — who sampled with $18 \mathrm{~mm}$ mesh seines and 100 to $150 \mathrm{~mm}$ mesh gill nets — stated, 'most species .... were present as both juveniles and adults' and 'standing-crop estimates for the fishes occurring within the mangroves were amongst the highest recorded values for estuarine areas' .

\section{Future directions}

The limitations above are important to consider when planning future studies. Given the history of the literature, it appears likely that future studies will continue to examine its spatio-temporal patterns of mangrove use by fishes. In general, studies that examine fish and habitat features at multiple spatial and temporal scales will be more valuable than those that examine at only one scale. Irrespective of scale, studies that examine both the mean and variance of abiotic and biotic metrics will provide more insight than those that only consider 'static' measures at the time of sampling. Power analysis and/or sampling efficiency evaluation are exceedingly rare in the literature, but are needed for mangrove fishes research to gain the attention it deserves (Ley et al. 1999). It is possible that statistical treatments such as these have been lacking in the literature partly because, at the species-specific level, 'zero-laden' fish abundance datasets are typical and less than desirable for traditional statistical treatments. However, the problem of rarity is widespread in ecological studies (Gaston 1994), including those on coral reef fishes (Jones et al. 2002). Researchers examining species-specific fish abundance data will benefit from the work of Aitchison (1955), Pennington (1983), Lo et al. (1992) and Johnson et al. (1999).

Several scientists are moving the study of mangrove fishes beyond pattern recognition towards more ecologically meaningful landscape-scale approaches, including habitat connectivity, suitability, and the contribution of mangrove habitats in support of adult fish populations (e.g. Pittman et al. 2004, Sheaves 2005, Mumby 2006). However, the need for species- and lifestage-specific information on growth, mortality, and secondary production rates remains. Although sufficient age-length, biomass and size-distribution data exist for several species to generate habitat-specific production estimates, this step has yet to be taken for mangrove fishes. Attaining accurate home ranges and movement rates for mangrove fishes represents an additional and significant challenge towards linking juvenile and adult stocks. Studies that examine habitat quality and availability are also needed to determine what makes some mangroves more important fish habitats than others.

Acknowledgements. This work was derived from a portion of a doctoral dissertation by C. H. F. We thank the present and past library staff of the University of Miami's Rosenstiel School of Marine and Atmospheric Science (RSMAS), especially Helen Albertson and Gail Clement. We also appreciate the efforts of numerous students and staff of the international community at RSMAS for translating numerous publications. The comments and additional literature sources provided by 4 anonymous reviewers greatly improved this manuscript. This paper is Sustainable Fisheries Division Contribution SFD-2006-024. 


\section{LITERATURE CITED}

Acosta A (1997) Use of multi-mesh gillnets and trammel nets to estimate fish species composition in coral reef and mangroves in the southwest coast of Puerto Rico. Caribb J Sci 33:45-57

Adams A, Dahlgren C, Kellison GT, Kendall MS, Layman CA, Ley JA, Nagelkerken I, Serafy JE (2006) The juvenile contribution function of back reef systems. Mar Ecol Prog Ser 318:287-301

Aitchison J (1955) On the distribution of a positive random variable having a discrete probability mass at the origin. J Am Stat Assoc 50:901-908

Alongi DM (2002) Present state and future of the world's mangrove forests. Environ Conserv 29:331-349

Alvarez León R, Blanco Racedo J (1985) Composition of fish communities in the lagoon and estuarine complex of Cartagena Bay, Cienaga de Tesca and Cienaga Grande of Santa Marta, Colombian Caribbean. In: Yáñez-Arancibia A (ed) Fish community ecology in estuaries and coastal lagoons: towards an ecosystem integration. UNAM Press, Mexico City, p 535-656

Amadi AA, Kilham P, Mavuti KM (1990) A comparative ecology of estuaries in Nigeria. Hydrobiologia 208:27-38

Araujo FG, De Azevedo MCC, Silva MA, Pessanha ALM, Gomes ID, Da Cruz-Filho AG (2002) Environmental influences on the demersal fish assemblages in the Sepetiba Bay, Brazil. Estuaries 25:441-450

Atiqullah M, Shaukat SS, Qureshi N (1997) Diversity of fish communities at Sandspit Karachi coast, Pakistan. Oebalia 23:45-59

Austin HM (1971) A survey of the ichthyofauna of the mangroves of western Puerto Rico during December, 1967August, 1968. Caribb J Sci 11:27-39

Baran E, Hambrey J (1998) Mangrove conservation and coastal management in southeast Asia: What impact on fishery resources? Mar Pollut Bull 37:431-440

Barletta-Bergan A, Barletta M, Saint-Paul U (2002) Community structure and temporal variability of ichthyoplankton in North Brazilian mangrove creeks. J Fish Biol 61:33-51

Batista VS, Rego FN (1996) Análise de associações de peixes, em igarapés do estuário do Rio Tibiri, Maranhão. Rev Bras Biol 56:163-176

Beck MW, Heck KL, Able KW, Childers DL and 9 others (2001) The identification, conservation, and management of estuarine and marine nurseries for fish and invertebrates. BioScience 51:633-641

Bell JD, Pollard DA, Burchmore JJ, Pease BC, Middleton MJ (1984) Structure of a fish community in a temperate tidal mangrove creek in Botany Bay, New South Wales. Aust J Mar Freshw Res 35:33-46

Bell JD, Craik GJS, Pollard DA, Russell BC (1985) Estimating length frequency-distributions of large reef fish underwater. Coral Reefs 4:41-44

Bellwood DR, Hughes TP, Folke C, Nystrom M (2004) Confronting the coral reef crisis. Nature 429:827-833

Benedetti-Cecchi L (2003) The importance of the variance around the mean effect size of ecological processes. Ecology 84:2335-2346

Blaber SJM (1980) Fish of the Trinity Inlet system of north Queensland with notes on the ecology of fish faunas of tropical Indo-Pacific estuaries. Aust J Mar Freshw Res 31: 137-146

Blaber SJM (2000) Tropical estuarine fishes: ecology, exploitation, and conservation. Blackwell Science, London

Blaber SJM (2002) 'Fish in hot water': the challenges facing fish and fisheries research in tropical estuaries. J Fish Biol 61:1-20
Blaber SJM, Blaber TG (1980) Factors affecting the distribution of juvenile estuarine and inshore fish. J Fish Biol 17:143-162

Blaber SJM, Milton DA (1990) Species composition, community structure and zoogeography of fishes of mangrove estuaries in the Solomon Islands. Mar Biol 105:259-267

Blaber SJM, Young JW, Dunning MC (1985) Community structure and zoogeographic affinities of the coastal fishes of the Dampier Region of north-western Australia. Aust J Mar Freshw Res 36:247-266

Blaber SJM, Brewer DT, Salini JP (1989) Species composition and biomasses of fishes in different habitats of a tropical northern Australian estuary: their occurrence in the adjoining sea and estuarine dependence. Estuar Coast Shelf Sci 29:509-531

Blaber SJM, Brewer DT, Harris AN (1994) Distribution, biomass and community structure of demersal fishes of the Gulf of Carpentaria, Australia. Aust J Mar Freshw Res 45: 375-396

Boeseman M (1963) An annotated list of fishes from the Niger delta. Zool Verh 61:1-54

Boltachev AR (1991) Species composition in the estuarine ichthyocene of the mangrove zone of Guinea. J Ichthyol 31:67-75

Boujard T, Rojas-Beltran R (1988) Longitudinal zonation of the fish population of the Sinnamary River (French Guiana). Rev Hydrobiol Trop 21:47-61

Boulon RH Jr (1992) Use of mangrove prop root habitats by fish in the northern US Virgin Islands. Proc Gulf Caribb Fish Inst 41:189-204

Branch GM, Grindley JR (1979) Ecology of southern African estuaries. Part XI. Mngazana: a mangrove estuary in Transkei. S Afr J Zool 14:149-170

Cervigón F (1985) The ichthyofauna of the Orinoco estuarine water delta in the West Atlantic coast, Caribbean. In: Yáñez-Arancibia A (ed) Fish community ecology in estuaries and coastal lagoons: towards an ecosystem integration. UNAM Press, Mexico City, p 57-78

Chaves P, Bouchereau JL (1999) Biodiversity and dynamics of ichthyic communities in the mangrove of Guaratuba, Brazil. Oceanol Acta 22:353-364

Chaves P, Correa MFM (1998) Composicao ictiofaunistical da area de manguezal da Baia de Guaratuba, Parana, Basil. Rev Bras Biol 15:195-202

Chaves TC, Vendel AL (2001) Nota complementar sobre a composicao ictiofaunistica da Baia de Guaratuba, Parana, Brasil. Rev Bras Biol 18:349-352

Cheal AJ, Thompson AA (1997) Comparing visual counts of coral reef fish: implications of transect width and species selection. Mar Ecol Prog Ser 158:241-248

Chong VC, Sasekumar A, Leh MUC, D'Cruz R (1990) The fish and prawn communities of a Malaysian coastal mangrove system, with comparisons to adjacent mud flats and inshore waters. Estuar Coast Shelf Sci 31:703-722

Claro R, García-Arteaga JP (1993) Fish community structure on mangroves from the Insular Group Sabana-Camaguey, Cuba. Avicennia 0:60-83

Claro R, Lindeman KC, Parenti LR (2001) Ecology of the marine fishes of Cuba. Smithsonian Institution Press, Washington, DC

Cocheret de la Morinière E, Pollux BJA, Nagelkerken I, van der Velde G (2002) Post-settlement life cycle migration patterns and habitat preference of coral reef fish that use seagrass and mangrove habitats as nurseries. Estuar Coast Shelf Sci 55:309-321

Cocheret de la Morinière E, Nagelkerken I, van der Meij H, van der Velde G (2004) What attracts juvenile coral reef fish to mangroves: habitat complexity or shade? Mar Biol 144: 
$139-145$

Collette BB (1983) Mangrove fishes of New Guinea. In: Teas HJ Biology and ecology of mangroves. Dr. W. Junk Publishers, The Hague, p 91-102

Connell JH (1978) Diversity in tropical rain forests and coral reefs. Science 199:1302-1310

Dankwa HR, Gordon C (2002) The fish and fisheries of the Lower Volta mangrove swamps in Ghana. Afr J Sci Technol (Sci Eng Ser) 3:25-32

Davis TLO (1988) Temporal changes in the fish fauna entering a tidal swamp system in tropical Australia. Environ Biol Fish 21:161-172

Day JH (1974) The ecology of Morrumbene estuary, Mozambique. Trans R Soc S Afr 41:43-97

Dennis GD (1992) Island mangrove habitats as spawning and nursery areas for commercially important fishes in the Caribbean. Proc Gulf Caribb Fish Inst 41:205-225

Faunce CH, Serafy JE, Lorenz JJ (2004) Density-habitat relationships of mangrove creek fishes within the southeastern saline Everglades (USA), with reference to managed freshwater releases. Wetlands Ecol Manag 12:377-394

Flores-Verdugo F, González-Farias F, Ramírez-Flores $\mathrm{O}$, Amezcua-Linares A, Yáñez-Arancibia A, Alvarez-Rubio M, Day JW Jr (1990) Mangrove ecology, aquatic primary productivity, and fish community dynamics in the TeacapanAgua Brava lagoon-estuarine system (Mexican Pacific). Estuaries 13:219-230

Gaston KJ (1994) Rarity. Chapman \& Hall, London

Gillanders BM, Able KW, Brown JA, Eggleston DB, Sheridan PF (2003) Evidence of connectivity between juvenile and adult habitats for mobile marine fauna: an important component of nurseries. Mar Ecol Prog Ser 247:281-295

Gonzalez-Acosta AF, De la Cruz Agüero J, Ruiz-Campos G (1999) Ichthyofauna associated to El Conchalito mangrove swamp, Ensenada de La Paz, Baja California Sur, Mexico. Investigaciones Marinas CICIMAR 14:121-131

Greene LE, Alevizon WS (1989) Comparative accuracies of visual assessment methods for coral reef fishes. Bull Mar Sci 44:899-912

Hajisamae S, Chou LM (2003) Do shallow water habitats of an impacted coastal strait serve as nursery grounds for fish? Estuar Coast Shelf Sci 56:281-290

Halliday IA, Young WR (1996) Density, biomass and species composition of fish in a subtropical Rhizophora stylosa mangrove forest. Mar Freshw Res 47:609-615

He B, Fan H, Mo Z (2001) Study on species diversity of fishes in mangrove area of Yingluo Bay, Guangxi province. J Trop Oceanogr 20:74-79

Heck JL, Hays G, Orth RJ (2003) Critical evaluation of the nursery role hypothesis for seagrass meadows. Mar Ecol Prog Ser 253:123-136

Holm RF (1977) The standing crop of fishes in a tropical marine lagoon. Fla Sci 40:258-261

Ikejima K, Tongnunui P, Medej T, Taniuchi T (2003) Juvenile and small fishes in a mangrove estuary in Trang Province, Thailand: seasonal and habitat differences. Estuar Coast Shelf Sci 56:447-457

Inger RE (1955) Ecological notes on the fish fauna of a coastal drainage of North Borneo. Fieldiana Zool 37:47-90

Janekarn V (1993) Species composition and annual population growth of fishes in front of a mangrove in Phang-Nga Bay, the Andaman Sea, Thailand. Phuket Mar Biol Cent (Spec. Publ.) 12:131-140

Janekarn V, Boonruang P (1986) Composition and occurrence of fish larvae in mangrove areas along the east coast of Phuket Island, western peninsular, Thailand. Phuket Mar Biol Cent Res Bull 44:1-22
Johnson DR, Funicelli NA, Bohnsack JA (1999) Effectiveness of an existing estuarine no-take fish sanctuary within the Kennedy Space Center, Florida. North Am J Fish Manag 19:436-453

Jones GP, Caley MJ, Munday PL (2002) Rarity in coral reef fish communities. In: Sale PF (ed) Coral reef fishes: dynamics and diversity in a complex ecosystem. Academic Press, San Diego, CA, p 81-102

Kendall MS, Christensen JD, Hillis-Starr Z (2003) Multi-scale data used to analyze the spatial distribution of French grunts, Haemulon flavolineatum, relative to hard and soft bottom in a benthic landscape. Environ Biol Fish 66:19-26

Kimani EN, Mwatha GK, Wakwabi EO, Ntiba JM, Okoth BK (1996) Fishes of a shallow tropical mangrove estuary, Gazi, Kenya. Mar Freshw Res 47:857-868

Krishnamurthy K, Jeyasslan MJP (1981) The early life history of fishes from Pichavaram mangrove ecosystem of India. In: Lasker R, Sherman K (eds) The early life history of fish: recent studies. Second ICES Symposium. Cons Int Explor Mer, Palegade 2-4, Copenhagen, p 416-423

Kuo S, Lin H, Shao K (1999) Fish assemblages in the mangrove creeks of northern and southern Taiwan. Estuaries 22: $1004-1015$

Laegdsgaard P, Johnson CR (1995) Mangrove habitats as nurseries: unique assemblages of juvenile fish in subtropical mangroves in eastern Australia. Mar Ecol Prog Ser 126:67-81

Laegdsgaard P, Johnson CR (2001) Why do juvenile fish utilize mangrove habitats? J Exp Mar Biol Ecol 257:229-253

Lal PN (1984) Coastal fisheries and the management of mangrove resources in Fiji. SPC Fish Newsl:15-23

Laroche J, Baran E, Rasoanandrasana NB (1997) Temporal patterns in a fish assemblage of a semiarid mangrove zone in Madagascar. J Fish Biol 51:3-20

Lasserre G, Toffart JL (1977) Echantillonnage et structure des populations ichthyologiques des mangroves de Guadeloupe en Septembre 1975. Cybium 3:115-127

Leigh EG (1990) Community diversity and environmental stability-a reexamination. Trends Ecol Evol 5:340-344

Ley JA, McIvor CC (2001) Linkages between estuarine and reef fish assemblages: enhancement by the presence of well-developed mangrove shorelines. In: Porter JW, Porter KG (eds) The Everglades, Florida Bay, and coral reefs of the Florida Keys: an ecosystem sourcebook. CRC Press, Boca Raton, FL, p 539-562

Ley JA, McIvor CC, Montague CL (1999) Fishes in mangrove prop-root habitats of northeastern Florida Bay: distinct assemblages across an estuarine gradient. Estuar Coast Shelf Sci 48:701-723

Lin HJ, Shao KT (1999) Seasonal and diel changes in a subtropical mangrove fish assemblage. Bull Mar Sci:775-794

Lindeman KC, Snyder DB (1999) Nearshore hardbottom fishes of southeast Florida and effects of habitat burial caused by dredging. Fish Bull 97:508-525

Little MC, Reay PJ, Grove SJ (1988a) Distribution gradients of ichthyoplankton in an East African mangrove creek. Estuar Coast Shelf Sci 26:669-677

Little MC, Reay PJ, Grove SJ (1988b) The fish community of an East African mangrove creek. J Fish Biol 32:729-747

Lo NCH, Jacobson LD, Squire JL (1992) Indexes of relative abundance from fish spotter data dased on Delta-Lognormal models. Can J Fish Aquat Sci 49:2515-2526

Lorenz JJ (1999) The response of fishes to physicochemical changes in the mangroves of northeast Florida Bay. Estuaries 22:500-517

Louis M, Bouchon C, Bouchon-Navaro Y (1992) L'ichtyofaune de mangrove dans la Baie de Fort-de-France (Martinique). Cybium 16:291-305 
Louis M, Bouchon C, Bouchon-Navaro Y (1995) Spatial and temporal variations of mangrove fish assemblages in Martinique (French West Indies). Hydrobiologia 295:275-284

Louis M, Lam Hoai T, Lasserre G (1985) Résultats préliminaires sur le recrutement en poissons dans deux lagunes des mangroves de Guadeloupe: Belle-Plaine et Manche-à-Eau. Rev Hydrobiol Trop 18:249-265

Lugendo BR, Pronker A, Cornelissen I, de Groene A, Nagelkerken I, Dorenbosch M, van der Velde G, Mgaya YD (2005) Habitat utilisation by juveniles of commercially important fish species in a marine embayment in Zanzibar, Tanzania. Aquat Living Resour 18:149-158

Lugo AE, Snedaker SC (1974) The ecology of mangroves. Annu Rev Ecol Syst 5:39-64

Manly BFJ, McDonald LL, Thomas DL (1993) Resource selection by animals: statistical design and analysis for field studies. Chapman \& Hall, London

Martínez AM, Contreras S, Maravilla O (1982) Abundancia y diversidad de la ictiofauna, en tres areas de manglar de la Bahía de la Paz, México. Trans Cibcasio 6:138-151

McIvor CC, Odum WE (1986) The flume net: a quantitative method for sampling fishes and macrocrustaceans on tidal marsh surfaces. Estuaries 9:219-224

Morton RM (1990) Community structure, density and standing crop of fishes in a subtropical Australian mangrove area. Mar Biol 105:385-394

Mullin SJ (1995) Estuarine fish populations among red mangrove prop roots of small overwash islands. Wetlands 15: 324-329

Mumby PJ (2006) Connectivity of reef fish between mangroves and coral reefs: algorithms for the design of marine reserves. Biol Conserv 128:215-222

Nagelkerken I, van der Velde G (2002) Do non-estuarine mangroves harbour higher densities of juvenile fish than adjacent shallow-water and coral reef habitats in Curaçao (Netherlands Antilles)? Mar Ecol Prog Ser 245:191-204

Nagelkerken I, Dorenbosch M, Verberk WCEP, Cocheret de la Morinière E, van der Velde G (2000a) Day-night shifts of fishes between shallow-water biotopes of a Caribbean bay, with emphasis on the nocturnal feeding of Haemulidae and Lutjanidae. Mar Ecol Prog Ser 194:55-64

Nagelkerken I, Dorenbosch M, Verberk WCEP, Cocheret de la Morinière E, van der Velde G (2000b) Importance of shallow-water biotopes of a Caribbean bay for juvenile coral reef fishes: patterns in biotope association, community structure and spatial distribution. Mar Ecol Prog Ser 202:175-192

Nagelkerken I, van der Velde G, Gorissen MW, Meijer GJ, van't Hof $T$, den Hartog C (2000c) Importance of mangroves, seagrass beds and the shallow coral reef as a nursery for important coral reef fishes, using a visual census technique. Estuar Coast Shelf Sci 51:31-44

Nagelkerken I, Kleijnen S, Klop T, van den Brand RACJ, Cocheret de la Morinière EC, van der Velde G (2001) Dependence of Caribbean reef fishes on mangroves and seagrass beds as nursery habitats: a comparison of fish faunas between bays with and without mangroves/seagrass beds. Mar Ecol Prog Ser 214:225-235

Nagelkerken I, Roberts CM, van der Velde G, Dorenbosch M, van Riel MC, Cocheret de la Morinière E, Nienhuis $\mathrm{PH}$ (2002) How important are mangroves and seagrass beds for coral-reef fish? The nursery hypothesis tested on an island scale. Mar Ecol Prog Ser 244:299-305

Newman SP, Gruber SH (2002) Comparison of mangrove and seagrass fish and macroinvertebrate communities in Bimini. Bahamas J Sci 9:19-27

Nwadukwe FO (1995) Species abundance and seasonal varia- tions in catch from two mangrove habitats in the Lagos Lagoon. Environ Ecol 13:121-128

Odum WE, McIvor CC, Smith TJ, III (1982) Ecology of the mangroves of south Florida: a community profile. Office of Biological Services, Fish and Wildlife Service, US Dept. of Interior, Washington, DC

Paranagua MN, Eskinazi-Leça E (1985) Ecology of a northern tropical estuary in Brazil and technological perspectives in fish culture. In: Yáñez-Arancibia A (ed) Fish community ecology in estuaries and coastal lagoons: towards an ecosystem integration. UNAM Press, Mexico City, p 595-614

Pennington M (1983) Efficient estimators of abundance, for fish and plankton surveys. Biometrics 39:281-286

Phillips PC (1981a) Annotated checklist of fishes at Jiquilisco Bay, El Salvador. Rev Biol Trop 29:45-58

Phillips PC (1981b) Diversity and fish community structure in a central American mangrove embayment. Rev Biol Trop 29:227-236

Pinto L (1987) Environmental factors influencing the occurrence of juvenile fish in the mangroves of Pagbilao, Philippines. Hydrobiologia 150:283-301

Pinto L, Punchihewa NN (1996) Utilization of mangroves and seagrasses by fishes in the Negombo Estuary, Sri Lanka. Mar Biol 126:333-345

Pittman SJ, McAlpine CA, Pittman KM (2004) Linking fish and prawns to their environment: a hierarchical landscape approach. Mar Ecol Prog Ser 283:233-254

Pollard DA, Hannan JC (1994) The ecological effects of structural flood mitigation works on fish habitats and fish communities in the lower Clarence River system of southeastern Australia. Estuaries 17:427-461

Primavera JH (1997) Fish predation on mangrove-associated penaeids: the role of structures and substrate. J Exp Mar Biol Ecol 215:205-216

Quinn NJ (1980) Analysis of temporal changes in fish assemblages in Serpentine Creek, Queensland. Environ Biol Fish 5:117-133

Quinn NJ, Kojis BJ (1985) Does the presence of coral reefs in proximity to a tropical estuary affect the estuarine fish assemblage? In: Harmelin-Vivien M, Salvat B, La Croix C, Gabrie C, Toffart JL (eds) Proc Fifth Int Coral Reef Congr, Tahiti, 27 May-1 Jun 1985, Miscellaneous papers (A), Vol 5. Antenne Museum-EPHE, Moorea, p 445-450

Robertson AI, Duke NC (1987) Mangroves as nursery sites: comparisons of the abundance and species composition of fish and crustaceans in mangroves and other nearshore habitats in tropical Australia. Mar Biol 96:193-205

Robertson AI, Duke NC (1990a) Mangrove fish-communities in tropical Queensland, Australia: spatial and temporal patterns in densities, biomass and community structure. Mar Biol 104:369-379

Robertson AI, Duke NC (1990b) Recruitment, growth and residence time of fishes in a tropical Australian mangrove system. Estuar Coast Shelf Sci 31:723-743

Rojas JRM, Castro M, Pizarro JF (1994a) Lista agregada de peces en tres zonas de manglar del Golfo de Nicoya, Costa Rica. Uniciencia 11:89-96

Rojas JRM, Pizarro JF, Castro MV (1994b) Diversidad y abundancia íctica en tres áreas de manglar en el Golfo de Nicoya, Costa Rica. Rev Biol Trop 42:663-672

Rönnbäck P, Troell M, Kautsky N, Primavera JH (1999) Distribution pattern of shrimps and fish among Avicennia and Rhizophora microhabitats in the Pagbilao Mangroves, Philippines. Estuar Coast Shelf Sci 48:223-234

Rooker JR, Dennis GD (1991) Diel, lunar and seasonal changes in a mangrove fish assemblage off southwestern Puerto 
Rico. Bull Mar Sci 49:684-698

Rozas LP, Minello TJ (1997) Estimating densities of small fishes and decapod crustaceans in shallow estuarine habitats: a review of sampling design with focus on gear selection. Estuaries 20:199-213

Russ GR, Stockwell B, Alcala AC (2005) Inferring versus measuring rates of recovery in no-take marine reserves. Mar Ecol Prog Ser 292:1-12

Sasekumar A, Chong VC, Leh MU, D'Cruz R (1992) Mangroves as a habitat for fish prawns. Hydrobiologia 247: 195-207

Savage RE (1931) The relation between the feeding of the herring off the east coast of England and the plankton of the surrounding waters. Fish Invest Lond Ser II 12:1-88

Sedberry GR, Carter J (1993) The fish community of a shallow tropical lagoon in Belize, Central America. Estuaries 16:198-215

Serafy JE, Faunce CH, Lorenz JJ (2003) Mangrove shoreline fishes of Biscayne Bay, Florida. Bull Mar Sci 72:161-180

Sheaves MJ (1992) Patterns of distribution and abundance of fishes in different habitats of a mangrove-lined tropical estuary, as determined by fish trapping. Aust J Mar Freshw Res 43:1461-1479

Sheaves M (1995) Large lutjanid and serranid fishes in tropical estuaries: Are they adults or juveniles? Mar Ecol Prog Ser 129:31-40

Sheaves MJ (1998) Spatial patterns in estuarine fish faunas in tropical Queensland: a reflection of interaction between long-term physical and biological processes? Mar Freshw Res 49:31-40

Sheaves M (2005) Nature and consequences of biological connectivity in mangrove systems. Mar Ecol Prog Ser 302: 293-305

Sheridan PF (1992) Comparative habitat utilization by estuarine macrofauna within the mangrove ecosystem of Rookery Bay, Florida. Bull Mar Sci 50:21-39

Sheridan P, Hays C (2003) Are mangroves nursery habitat for transient fishes and decapods? Wetlands 23:449-458

Snedaker SC (1989) Overview of ecology of mangroves and information needs for Florida Bay. Bull Mar Sci 44:341-347

Sogard SM, Powell GVN, Holmquist JG (1989) Spatialdistribution and trends in abundance of fishes residing in seagrass meadows on Florida Bay mudbanks. Bull Mar Sci 44:179-199

Spalding M, Blasco F, Field C (1997) World Mangrove Atlas. The International Society for Mangrove Ecosystems (ISME), Okinawa

St. John J, Russ GR, Gladstone W (1990) Accuracy and bias of visual estimates of numbers, size structure and biomass of a coral reef fish. Mar Ecol Prog Ser 64:253-262

Stoner AW (1986) Community structure of the demersal fish species of Laguna Joyuda, Puerto Rico. Estuaries 9:142-152

Thayer GW, Sheridan P (1999) Fish and aquatic invertebrate use of the mangrove prop-root habitat in Florida: a review. In: Yáñez-Arancibia A, Lara-Domínguez AL (eds) Ecosistemas de Manglar en America Tropical. Instituto de Ecologia, A.C. Mexico, UICN/ORMA Costa Rica, NOAA/NMFS Silver Spring, MD, p 380

Thayer GW, Colby DR, Hettler WF Jr (1987) Utilization of the red mangrove prop root habitat by fishes in South Florida. Mar Ecol Prog Ser 35:25-38

Thia-Eng C (11973) An ecological study of the Ponggol estuary in Singapore. Hydrobiol 43:3-4

Thollot P (1992) Importance des mangroves pour la faune ichtyologique des récifs coralliens de Nouvelle-Calédonie. Cybium 16:331-344

Thollot P, Kulbicki M (1988) Overlap between the fish fauna inventories of coral reefs, soft bottoms and mangroves in Saint-Vincent Bay (New Caledonia). Proc Sixth Int Coral Reef Symp 2, Townsville, p 613-618

Thompson AA, Mapstone BD (1997) Observer effects and training in underwater visual surveys of reef fishes. Mar Ecol Prog Ser 154:53-63

Tobias WJ (2001) Mangrove habitat as nursery grounds for recreationally important fish species-Great Pond, St. Croix, U.S. Virgin Islands. Proc Gulf Caribb Fish Inst 52:468-487

Tongnunui P, Ikejima K, Yamane T, Horinouchi M, Medej T, Sano M, Kurokura H, Taniuchi T (2002) Fish fauna of the Sikao Creek mangrove estuary, Trang, Thailand. Fish Sci 68:10-17

Tzeng W, Wang Y (1992) Structure, composition and seasonal dynamics of the larval and juvenile fish community in the mangrove estuary of Tanshui river, Taiwan. Mar Biol 113: 481-490

Uieda VS, Uieda W (2001) Species composition and spatial distribution of a stream fish assemblage in the east coast of Brazil: comparison oftwo field study methodologies. Brazilian J Biol 61:377-388

USDOC (1996) Magnusen-Stevens Fishery Conservation and Management Act as amended through October 11, 1996, National Oceanic and Atmospheric Administration Technical Memorandum NMFS-F/SPO-23

Valdés-Muñoz E (1981) Estructura y diversidad de la ictiofauna de los manglares de Punta del Este, Isla de la Juventud. Cienc Biol 6:111-124

Valdés-Muñoz E, Mochek AD (2001) Behavior of marine fishes of the Cuban shelf. In: Claro R, Lindeman KC, Parenti LR (eds) Ecology of the marine fishes of Cuba. Smithsonian Institution Press, Washington, DC, p 73-114

van der Velde G, Gorissen MW, Denhartog C, Vanthoff T, Meijer GJ (1992) Importance of the Lac-Lagoon (Bonaire, Netherlands-Antilles) for a selected number of reef fish species. Hydrobiologia 247:139-140

Vance DJ, Haywood MDE, Heales DS, Kenyon RA, Loneragan NR, Pendrey RC (1996) How far do prawns and fish move into mangroves? Distribution of juvenile banana prawns Penaeus merguiensis and fish in a tropical mangrove forest in northern Australia. Mar Ecol Prog Ser 131:115-124

Vega-Cendejas ME, de Santillana MH (2004) Fish community structure and dynamics in a coastal hypersaline lagoon: Rio Lagartos, Yucatan, Mexico. Estuar Coast Shelf Sci 60:285-299

Vega-Cendejas ME, Ordóñez U, Hernández M (1994) DayNight variation of fish population in the mangrove of Celestun lagoon, Mexico. Int J Ecol Env Sci 20:99-108

Vidy G (2000) Estuarine and mangrove systems and the nursery concept: which is which? The case of the Sine Saloum system (Senegal). Wetl Ecol Manag:37-51

Vose FE, Bell SS (1994) Resident fishes and macrobenthos in mangrove-rimmed habitats: evaluation of habitat restoration by hydrologic modification. Estuaries 17:585-596

Warburton K (1978) Community structure, abundance and diversity of fish in a Mexican coastal lagoon system. Estuar Coast Mar Sci 7:497-519

Weinstein MP, Courtney CM, Kinch JC (1977) The Marco Island estuary: a summary of physicochemical and biological parameters. Fla Sci 40:97-124

Weng HT (1990) Fish in shallow areas in Moreton Bay, Queensland and factors affecting their distribution. Estuar Coast Shelf Sci 30:569-578

Williamson I, King C, Mather PB (1994) A comparison of fish communities in unmodified and modified inshore habitats of Raby Bay, Queensland. Estuar Coast Shelf Sci 39: 401-411

Wright JM (1986) The ecology of fish occurring in shallow 
water creeks of a Nigerian mangrove swamp. J Fish Biol 29:431-441

Yáñez-Arancibia A (1985) Fish community ecology in estuaries and coastal lagoons: towards an ecosystem integration. UNAM Press, Mexico

Yáñez-Arancibia A, Lara-Domínguez AL, Rojas-Galaviz JL, Sanchez-Gil P, Day JW Jr, Madden CJ (1988) Seasonal bio-

Editorial responsibility: Howard I. Browman (Associate Editor-in-Chief), Storebø, Norway mass and diversity of estuarine fishes coupled with tropical habitat heterogeneity (southern Gulf of Mexico). J Fish Biol 33:191-200

Yáñez-Arancibia A, Lara-Domínguez AL, Day JW Jr (1993) Interactions between mangrove and seagrass habitats mediated by estuarine nekton assemblages: coupling of primary and secondary production. Hydrobiologia 264:1-12

Submitted: February 17, 2005; Accepted: May 24, 2006 Proofs received from author(s): July 12, 2006 